\title{
Microstate Democracy Revisited: Developments in Time and Space
}

\author{
Dag Anckar* \\ Professor Emeritus of Political Science, Åbo Akademi University, Department of Political Science, Biskopsgatan 15, \\ 20500 Åbo 50, Finland
}

\begin{abstract}
Research on small state politics suggests that smallness reinforces popular rule and that small states are more likely to be democratic than large states. The mechanisms that serve to transform smallness into democratic conduct remain, however, under-researched, and this study contributes by probing the very foundations of the belief that small size fosters democracy. For smallness really to count, small states should display a propensity for democracy at different points of time and where ever they are on the globe. If this is not the case, then, obviously, the size factor is surpassed by factors that relate to diffusion, culture or to regional circumstances rather than to smallness per se. The empirical findings suggesting that this is indeed the case, the study ends on a general discussion of circumstances that are likely to enhance or weaken the link between small size and democracy.
\end{abstract}

\section{INTRODUCTION}

One well-established finding in research on small state politics is that smallness reinforces popular rule and that small states are therefore more likely to be democratic than large states. This assertion is rooted in several individual investigations and reports, which suggest, for instance, that there is a significant correlation between small island states and democracy (Griffith \& Sedoc-Dahleberg, 1997; Clague, Gleason \& Knack, 2001; C. Anckar, 2008), that close to 75\% of states with populations of under one million were democracies in 1998, compared to a much smaller portion of larger countries (Diamond \& Tsalik, 1999: 117), and that state size is a more useful category than degree of development or geographic location for understanding the prerequisites for democracy (Ott, 2000). An observation from the year 1999 is that whereas some three quarters of the microstates in the world were democracies, the same was true of only about one third of other states (D. Anckar, 2002: 377-378). Summarizing these and other similar studies, Henry Srebrnik concludes that small country size has been shown to be conducive to democracy (2004: 330), and that 'more and more statistical and anecdotic evidence indicates that a significant feature about small island jurisdictions has been their ability to maintain democratic political systems' (2004: 339).

The mechanisms that serve to transform smallness into democratic conduct remain, however, under-researched, and Srebrnik ends in his above-mentioned essay, focusing the particular case of small island states, on the somewhat pessimistic note that 'maybe we will never be able to isolate scientifically that elusive independent variable that seems to make islands more conducive to democracy' (2004: 339). This study certainly ogles at the question why smallness appears to promote democracy, and certainly participates in the ongoing hunt for essential variables and explanations.

*Address correspondence to this author at the Professor Emeritus of Political Science, Åbo Akademi University, Department of Political Science, Biskopsgatan 15, 20500 Åbo 50, Finland; Tel: (358)-2-2154316 (office); Fax: (358)-2-2154585; E-mail: dag.anckar@abo.fi
Still, the emphasis of the study is elsewhere. Rather than investigating systematically democracy determinants, the study probes by examining the microstates of the world the very foundations of the belief that small size fosters democracy. Investigating the ability of the smallness-fostersdemocracy doctrine to survive a durability test, the effort is guided by two particular conceptions of robustness. First, if small size implies an ability to promote democracy, then this ability should be immune to variations in time. For smallness really to count, the expectation is that small states are always, at different points of time, more democratic than larger states. If this is not the case, then, obviously, the impact of factors and mechanisms in the terrain between size and democracy is for some reason time-dependent, meaning that changes over time have cleared the way for the working of such factors and mechanisms on democracy requisites. Second, the ability to promote democracy should in like manner be immune to variations in space. For smallness really to count, small states should display a propensity for democracy where ever they are on the globe. If this is not the case, then, obviously, the size factor is surpassed by factors that relate to culture or to other regional circumstances rather than to smallness per se.

The paper is organized in five main sections. Following this brief introduction, a second section presents considerations on materials and methodology. The subsequent third section deals with the time dimension and tries to lay down the extent to which the relation between small size and democracy is unaffected by variation over time. This section also deals with the kindred question of microstate mobility between democracy categories. Mapping the presence of microstates in different parts of the world, the fourth section turns to an evaluation of the stability in terms of geography of the relation between small size and democracy. Finally, a fifth section offers a summation as well as a discussion of the main findings.

\section{MATERIALS AND METHODOLOGY}

An implementation of the impending research task implies that three basic method problems can be solved in a 
satisfactory and coherent manner. First, the microstates of the world need to be identified. Second, in order to capture the development over time of microstates in terms of democratization, non-democratization and oscillation, the points at a time axis at which the microstates are to be observed must be established. Third, an apparatus must be designed for determining whether or not a specific microstate maintains at a specific point of time a democracy status. This section deals with these three method requirements, in that order.

(1) This study identifies as microstates countries which have one million inhabitants or less. This is the conventional method in political science studies for defining microstates. True, the ceiling is at times contested, and most microstates are in fact diminutive to an extent that occasions the question if this conventional method really is valid and relevant. For instance, out of a total of 42 microstates in 2006, no less than $80 \%$ reported populations of about 500.000 or less, while $60 \%$ had populations of about 300.000 or less (D. Anckar, 2007: 194-195). It would appear, therefore, that the conventional scale is somewhat imbalanced, eight units out of ten appearing on the lower half and six units out of ten appearing on the lowest third of the scale. However, to avoid confusion and to facilitate comparisons with other microstate studies, the standard one million ceiling is nevertheless applied here.

(2) To establish a time dimension and secure a sufficient spreading over time of empirical observations, four short time segments, each comprising three years, are laid down. The first segment covers the years 1974-1976, the second the years 1984-1986, the third the years 19941996, and the fourth, finally, the years 2004-2006. These observation points are selected partly out of materials considerations, which are to be explained shortly, and partly out of the ambition to cover with even intervals a relevant period of time, relevance implying the democratic transformation of the world's political landscape in the final quarter of the twentieth century (Hague \& Harrop, 2004: 35). Microstate status being defined in terms of population, figures for population size must be obtained for each of the four time segments, and different sources have been used. Whereas population figures for the first time segment (1974-1976) are from an internet source on population statistics and historical demography of all countries (http://www.populstat.info/), population figures for the second time segment (19841986) are obtained from World Economic and Business Review 1990. Concerning the third time segment (19941996), population figures are from an authoritative handbook on Political Systems of the World (Derbyshire \& Derbyshire, 1999), whereas, finally, the corresponding information for the fourth time segment (2004-2006) is covered by the Freedom House Map of Freedom for the respective years (http://www.freedomhouse.org/template.cfm?page $=15$ ). With one exception, the identification of the microstates populations has been unproblematic. The exception is Bhutan, different sources reporting even dramatically diverging population figures. For instance, the Derbyshire handbook (1999: 149) quotes an UN estimate of 1,641,000, but also notes that the Bhutanese government claims the official overall population to be as little as $600,000-850,000$. In reliance on the Bhutanese government more than the UN, Bhutan has been classified here as a microstate during the three first time segments.

The method of relying on population figures carries consequences, one of which is that the number of microstates may fluctuate between time segments and indeed even from one year to another. Over time, new microstates emerge in the wake of decolonization and independence efforts, and over time, old microstates disappear as they experience a population growth which surpasses the one million microstate threshold. The microstate population of the world is therefore in constant flux, and it is only natural that the population in 2006 is different and even much different from the corresponding population in, say, 1975. From this, again, two specific and related consequences follow. First, all microstates do not receive the same amount of attention in this study, some being in existence during the whole period of investigation, and other during shorter or very short periods only. Second, one goal of comparative research being the elimination of proper names of countries and dealing instead with conceptual categories and theoretical explanations (Peters, 1998: 105), this study takes one step in such a direction. The study is about smallness in general and small size as context rather than about particular small countries.

(3) To determine whether or not individual states are democracies, use is made of the annual freedom ratings provided by the Freedom House organization. Based on surveys provided by regional experts, consultants and human rights specialists as well as fact-finding missions and public sources, Freedom House monitors since 1972 the progress and decline of political rights and civil liberties in all the nations of the world and in related territories. The reliance here on Freedom House data also explains the choice of time segments for this study, relevant and comparable figures for periods that precede the 1970s being unavailable. The Freedom House efforts are since 1978 published in a yearbook called Freedom in the World. In essence, the units are rated on sevencategory scales for political rights and civil liberties, and then, on the basis of these ratings, placed into one of the categories of 'Free', 'Partly Free' and 'Not Free'. On each scale, the value 1 represents the most free and value 7 the least free, and the placing of units in categories is dependent on the combined ratings. Generally, countries whose ratings average 1-2.5 are considered 'Free', whereas countries whose ratings average 3-5.5 are considered 'Partly Free' and countries whose ratings average 5.5-7 are considered 'Not Free'. Although it is certainly true that the Freedom House data do not discriminate in full between degrees of freedom and nonfreedom (Foweraker \& Krznaric, 2000: 767), the data are still widely used by social and political scientists (e.g. Lijphart, 1999), and are generally credited with validity as well as reliability. The operational formula which comes to use here denotes countries which are 'Free' as democratic, whereas countries which are 'Partly Free' or 'Not Free' suffer from popular rule shortcomings that are severe enough to merit classification in a non-democracy category. 
To summarize: for each of twelve measure points, located in four time segments, the microstate population of the world is identified, population size being the defining criterion. Each state in these twelve populations is then classified at each measure point as being democratic or non-democratic, the criterion being the Freedom House ranking of that state at the time of observation. This analysis provides a set of patterns, that describe permanencies as well as dynamics within the microstate universe, and these patterns form the basis of the empirical analyses and conclusions that follow.

\section{DEMOCRACIES AND NON-DEMOCRACIES}

The review of the empirical results may start from an inspection of the data in Table 1, which gives the number of democratic and non-democratic microstates during the twelve years that are investigated. This inspection suggests that the smallness-fosters-democracy thesis may indeed be called in question. Admittedly, this is not immediately evident from an inspection of the total picture. The research has provided in all 461 country classifications, and of these $56 \%$ are in the democracy category. Evidently, therefore, there seems to be an overall link between smallness and democracy, albeit this link is fairly weak. However, this finding is anything but robust in terms of time. The proportions between democratic and non-democratic countries during the first two time segments (1974-76 and 1984-86 respectively), which are internally fairly similar, are clearly different from the corresponding proportions during the third and fourth time segments (1994-1996 and 20042006 respectively), which are again internally fairly similar. During the first two segments $43 \%$ only of the country classifications are in the democracy category, whereas the majority of the classifications $(57 \%)$ are in the non- democracy category, but the outcome is clearly reversed during the third and fourth time segments, as the majority of the classifications (68\%) are now in the democracy category as against $32 \%$ in the non-democracy category. In other words, whereas earlier the microstate camp comprised nondemocracies more than democracies, this has later changed much, the vast majority of microstate classifications now being in the democracy category.

Of course, this does not imply that the doctrine of smallness always fostering democracy is falsified throughout. It is quite conceivable that a tendency towards non-democracy was in the 1970s and 1980s still more prominent among larger states than in small states, the implication of this being, then, that small states, although inclined towards non-democracy more than democracy, still outflanked larger states in terms of democracy dispositions. Several individual observations from the literature support this hypothesis, as they suggest that the overall number of democracies were still in the 1970s and 1980s fairly low, this indicating, then, that the corresponding number of microstate democracies given in Table $\mathbf{1}$ is, after all, competitive and noteworthy. Among relevant findings are the observation that there were in 1974 only 39 countries where multiparty national elections took place on a regular basis (Soudriette \& Ellis, 2006: 78), the observation that there were 43 consolidated democracies in the world between 1979 and 1989 (Stepan \& Skach, 1994: 121), the observation that in 1985 a total of 58 out of 147 countries were democracies (Vanhanen, 1990: 33), and the observation that in 1987 there were 66 electoral democracies among 167 states (Karatnycky, 2003: 105). Since, however, these counts depart from somewhat diverging notions and operationalizations of the democracy concept, the validity of comparisons may be called in question, and the safest route to establish an impact

Table 1. Number of Democratic and Non-Democratic Microstates in the World During Four Time Segments

\begin{tabular}{|c|c|c|c|}
\hline & Microstates N & Microstates, N Democratic/Non-democratic & Non-democratic Microstates, $\%$ \\
\hline 1974 & 30 & $13 / 17$ & 57 \\
\hline 1976 & 34 & $14 / 20$ & 59 \\
\hline 1974-76 (average) & 33 & $13 / 19$ & 59 \\
\hline 1985 & 38 & $17 / 21$ & 55 \\
\hline 1986 & 37 & $17 / 20$ & 54 \\
\hline 1984-86 (average) & 38 & $17 / 21$ & 56 \\
\hline 1994 & 42 & $28 / 14$ & 33 \\
\hline 1995 & 42 & $28 / 14$ & 33 \\
\hline 2004 & 41 & $28 / 13$ & 32 \\
\hline 2005 & 41 & $29 / 12$ & 29 \\
\hline 2006 & 42 & $29 / 13$ & 31 \\
\hline 2004-06 (average) & 41 & $29 / 13$ & 31 \\
\hline
\end{tabular}


of smallness is therefore to calculate for purposes of comparison the relevant democracy figures from the Freedom House data-base. Calculations by the present author show that it is indeed the case that smallness linked to democracy already during earlier phases. Whereas $41 \%$ of the microstates were democracies in the year 1976, the same was true of only $23 \%$ of the larger states. The situation had not changed much in 1986, $46 \%$ of the microstates and 30\% of the larger states being ranked as democracies.

Still, the fact remains that whereas microstates were earlier predominantly non-democratic, they have later become predominantly democratic. How, then, has this change come about? What features characterize the democratization of the microstate universe, and what factors may have contributed to democratization? Obviously, answers to these questions must be searched through a closer look at mobility patterns between democracy categories. This is done in the following by means of a general chart of the extent to which separate microstates have been ranked as democracies during the time period in question, and by means also of a detailed comparison of the situations in the years of 1986 and 2006, these two years disclosing, as evident from Table 1, quite different democracy profiles. In the general chart, to uncover the general empirical pattern, each microstate is placed in one of five categories. The first category comprises predominantly democratic units, i.e. microstates which have been ranked as democracies at all or almost all occasions they are subjected to classification. In the second category are placed countries which have been democratized over the years, starting out as non-democracies and then evolving into a democracy status which has been maintained, becoming permanent. The third category covers cases which have experienced opposite fortunes, starting out as democracies later to forfeit this status and become nondemocracies. In the fourth category are countries which have performed as oscillators, moving repeatedly to and from positions as democracies and non-democracies. Finally, the fifth category is about predominantly non-democratic units, i.e. microstates which have been ranked as non-democracies at all or almost all occasions they have been subjected to classification.

The findings are given in Table 2. The figures put in bracket after each individual state reflects the democratic record of that particular state. For instance, Bahamas (12-0) means that Bahamas has been classified by Freedom House at each of the twelve measure points, and that the outcome has been in each case that Bahamas is a democracy. The expression for democratized Cape Verde (6-6) implies that whereas this state was ranked as a non-democracy at the six first measure points, it was thereafter ranked as a democracy at the following six points. On the other hand, the same expression for non-democratized Fiji (6-6) tells that Fiji was ranked a democracy at the first six measure points, thereafter to decline into the rank of a non-democracy. The findings are intriguing, as they suggest a highly polarized microstate universe. Rather than being gradually democratized or nondemocratized, the states group into two opposite camps, both displaying predominant patterns. A total of 51 countries figure in the compilation in Table 2; of these, no less than 35 countries, equal to $69 \%$, are in the predominant categories. Of these 35 countries, 19 are in the predominantly democratic category, and 16 are in the predominantly nondemocratic category. Of the remaining 16 countries, 10 have experienced democratization over time, whereas three have been non-democratized, and another three are oscillators, turning from democracies to non-democracies and then again back to democracies.

A detailed comparison of the situations in the years of 1986 and 2006, which dates are selected here as representative years of earlier and more recent developments, reveals three reasons for the advancement of microstate democracy. First, a small handful of new independent microstates have emerged in the early 1990s from US colonial rule, all embarking upon independence as democracies. These cases are: the Marshall Islands (1991), the Federated States of Micronesia (1991), and Belau (1994). Second, the democratization - non-democratization traffic in the time period between 1986 and 2006 has produced a noticeable democracy net increase, as ten former nondemocracies have turned democratic as against two cases of non-democratization. The democratized units are: Andorra, Cape Verde, Cyprus, Grenada, Guyana, Liechtenstein, Monaco, Samoa, Sao Tomé and Príncipe, and Vanuatu, whereas the non-democratized units are Fiji and the Solomon Islands. Missing data concerning the diminutive European cases of Andorra, Liechtenstein and Monaco, all since long

\section{Table 2. Democratic Mobility in the Microstate Universe; 1974-2006}

Predominantly democratic ( $\mathrm{N}=19)$; democracy - non-democracy scores:

Bahamas (12-0), Barbados (12-0), Iceland (12-0), Luxembourg (12-0), Nauru (12-0), Belize (9-0), Dominica (9-0), Kiribati (9-0), San Marino (9-0), St Kitts-Nevis (7-0), St Lucia (7-0), St Vincent and the Grenadines (7-0), Tuvalu (7-0), Belau (6-0), Marshall Islands (6-0), Micronesia (6-0), Botswana (3-0), Mauritius (3-0), Trinidad and Tobago (3-0).

Democratized ( $\mathrm{N}=10)$; non-democracy - democracy scores:

Andorra (3-6), Cape Verde (6-6), Cyprus (3-9), Grenada (4-8), Guyana (6-6), Liechtenstein (3-6), Monaco (3-6), Samoa (6-6), Sao Tomé and Príncipe (56), Vanuatu 3-6).

Non-democratized $(\mathrm{N}=3)$; democracy - non-democracy scores:

Fiji (6-6), Gambia (3-3), Solomon Islands (4-3).

Oscillating ( $\mathrm{N}=3$ ); democracy - non-democracy - democracy scores:

Antigua-Barbuda (3-4-2), Malta (3-3-6), Suriname (1-6-3).

Predominantly non-democratic ( $\mathrm{N}=16)$; democracy - non-democracy scores:

Bahrain (0-12), Brunei (0-12), Equatorial Guinea (0-12), Qatar (0-12), Tonga (0-12), Comoros (0-11), Maldives (1-11), Bhutan (0-9), Djibouti (0-9), Swaziland (0-9), Seychelles (1-9), Guinea-Bissau (0-6), Gabon (0-5), Timor-Leste (0-3), Kuwait (0-2), Montenegro (0-1). 
independent states (Duursma, 1994), make these cases somewhat special, as they, upon being ranked in 1974-1976 as non-democracies disappeared for some inexplicable reason from the Freedom House rankings in 1984-1986. Later rankings, however, have again embraced these cases and have now conferred democracy status upon them. Finally, the third reason is technical in nature, as the democracy advantage is advanced by four non-democratic units disappearing in consequence of population growth from the microstate rank. These countries are Bhutan, Gambia, Guinea-Bissau and Swaziland. On the other hand, two newcomers, namely Timor-Leste and Montenegro, have entered the non-democracy camp.

A search for a common denominator in the democratization developments appears futile, as the factors that unleashed democratization were in separate cases quite different. For instance, there is very little to tie the democratization cases to the so-called third wave of democratization in the years 1974-1991, marked by the end of right-wing dictatorship in Southern Europe, the retreat of the generals in much of Latin America, and the collapse of communism in the Soviet Union and Eastern Europe (Huntington, 1991). True, Cape Verde (Clemente-Kersten, 1999) and Sao Tomé and Príncipe (Fleischhacker, 1999), both freed in 1975 as authoritarian one-party states from Portuguese rule, may be regarded as diffusion cases in point, as in these countries the creating of institutional conditions for competitive elections took place on the eve of the breakdown of the communist regimes. Other cases, however, are democratized along other lines. In some instances, the promotion to the democracy rank followed upon the countries in question simply altering essential clauses in their constitutions. Samoa became a democracy when in 1990 universal suffrage was introduced, voting rights being earlier restricted to bearers of traditional matai chiefly titles (Lawson, 1996: 148-151). The case of Liechtenstein is fairly similar, as the electoral enfranchisement of women at the national level was approved there in 1984, universal adult suffrage at the local level being passed in all communes shortly thereafter. In this same group is also Andorra, ranked as a democracy upon the adoption in 1993 of its first constitution, which defines the country as a parliamentary co-principality.

Other cases are illustrative of the initial difficulties that by evoking transitional unrest or reflecting authoritarian legacies plague democratizing countries; however, the cases are illustrative also of an inherent capacity of small states to neutralize and eventually overcome such difficulties. Emerging from condominium status (van Trease, 1995 a), Vanuatu experienced during her first independence years conflicts over the foreign policy orientation of the country (Arutangai, 1995) as well as a constitutional crisis (van Trease, 1995 b: 86-95); however, later developments have served to stabilize political life and have enabled the country to achieve, as stated in the recent literature, 'an admirable sense of national identity and coherence' (Hassall, 2007: 226). Antigua-Barbuda became upgraded in the 2005 Freedom House ratings thanks to a free and fair election in 2004 which marked the end of the tainted Bird dynasty which had dominated Antiguan politics for decades (Puddington \& Piano, 2005: 105). Independent in 1966 from Britain, Guyana grappled with a long-standing animosity between Afro-and Indo-Guyanese and pursued a militant and pro-socialist policy under the authoritarian leadership of Forbes Burnham, prime minister from independence to his death in 1985 (Lewis, 2001). Only in 1992 were the first free and fair elections held in the country (Manley, 1999: 448), and since these elections, later incidents of political and social turmoil notwithstanding, Guyana has been regarded a democratic state, walking in the Freedom House ratings a thin borderline between democracy and non-democracy.

In still other cases the initial difficulties were grave, as they took the form of armed conflicts with ethnic or political signatures. Again, however, the small state capacity to outlive crisis and advance towards democracy is conspicuous. In Grenada, independent in 1974 from British rule, a Marxist movement seized power in 1979 and suspended the constitution, later developments provoking in 1983 a joint US-Caribbean military intervention (Davidson, 1987: 79-137), and subsequent general elections in 1984 restoring the parliamentary system. The estimation that constitutional government now appears to be on firm ground in Grenada (Anderson, 1999: 430) is since 1985 confirmed by supporting Freedom House ratings. In this same group is also oscillating Suriname. The country embarked in 1975 on independence as a democratic nation, but experienced in 1980 a military takeover and a following guerrilla war (Dew, 1994). Upon a return in 1987 to civil rule, Suriname, described at that time as a 'troubled land' (Thorndike, 1990: 616), has gradually recovered, and is since recently again classified as a democracy. In Cyprus, independent in 1960 from British rule, the early political life of the country was polarized along ethnic lines, and repeated ethnically colored legal and political deadlocks caused severe tension (Joseph, 1999: 28; Royle, 2001: 152). The then military government of Greece sponsored in 1974 a coup against President Makarios, followed by invasion of Northern Cyprus by Turkey. Since then Cyprus has been a divided nation, and the subsequent positive Freedom House classifications of the country are based on the performance of the Greek section.

In a few cases, however, smallness has offered little shelter in regards to threats against democracy. Ethnic cleavages are a common denominator for the two prominent cases in this category. In Fiji, one of the world's most ethnically polarized countries (Davies, 2005: 47), ethnic rivalry between indigenous Fijians and Indo-Fijians triggered a military coup in 1987 , followed by the establishment of the 1990 constitution which guaranteed indigenous Fijian control of government (Lawson, 1991: 234-276). The introduction in 1997 upon international pressure of a less biased constitution served to restore to some extent the repute of the country; however, following general elections in 1999 and the installation of the country's first Indo-Fijian Prime Minister, a new coup shattered the new constitution and created an interim civil administration (Alley, 2000). In the wake of a new coup in late 2006 a military-appointed interim administration has now been installed (Lal, 2007). Once described as 'the shining example of democracy, multicultural harmony and development in the Pacific, and indeed a standard for the entire Third World' (Kay, 1993: 28), Fiji has now, for the time being at least, retarded into a cessation of democracy. The Solomon Islands embarked upon independence from Britain in 1978 with a Westminster-type democratic government; an evaluation 
some ten years later of the performance of the new state was that 'Democracy in its modern form may be a recent migrant to the Solomons, but it would appear to be settling in well' (Alasia, 1989: 150). However, this forecast has proved to be too optimistic. In 1998 tensions between the two largest ethnic groups in the Solomons erupted into open warfare. The country experienced a coup in 2000, and racially charged riots still plague political life in the country, which is presently regarded by many as a failed state (Larmour, 2005: 22-23). Apparently, modern democratic structures are still not sufficiently aligned with indigenous systems of power and authority (Moore, 2007: 193).

\section{THE REGIONAL PATTERN}

Turning now from time to space, the regional aspect of microstate democracy is illuminated in Table $\mathbf{3}$, which reports the distribution of classifications in the democracy and the non-democracy categories over five geographies. As evident from the Table, three democracy strongholds may be identified. The Caribbean region heads the list, no less than $82 \%$ of the classifications being in the democracy category and eight countries out of twelve being predominantly democratic. The small island community in the Pacific displays a fairly similar profile with $69 \%$ of the classifications in the democracy category and eight out of 11 countries being predominantly democratic or democratized. True, Fiji and Solomon Islands stand for nondemocratization, and in the Pacific camp is also Tonga, where democratic transition is still 'unfinished business' (Senituli, 2007). The third stronghold is Europe, an impressing $81 \%$ of the classifications being in the democracy category, and eight microstates out of nine being predominantly democratic or democratized. Furthermore, the sole exception, recently independent Montenegro, has been classified only once (2006) in the materials at hand, and does therefore not count for much in terms of deviation. In all, 17 out of the 19 predominantly oriented microstates in these three regions and 145 out of 158 separate classifications of these states $(=92 \%)$ are in the democracy camp. Whereas the small state dominance in the Caribbean and the Pacific render uncertain any comparison between small and larger states, such a comparison is possible in regards to Europe, and the overall democracy cachet of Europe notwithstanding, the close link between small size and democracy is still discernible in this region. Whereas in 2006 only one
European microstate out of nine was non-democratic, of larger states, according to Freedom House-based calculations by the present author, eight out of 29 belonged in the same group.

In contrast, the two remaining regions of Africa on the one hand and Middle East and Asia on the other, display a much different pattern, as these two regions appear close to immune to democracy. Concerning Africa, $78 \%$ of the classifications of microstate countries in this region are in the non-democracy category; furthermore, seven out of 12 separate countries are in the predominantly non-democratic category. On the other hand, Cape Verde and Sao Tomé and Príncipe are democratized, and Botswana and Mauritius are two notable African exceptions, both classified as democracies at three separate occasions in the materials at hand, and both answering well to descriptions in the literature, depicting Botswana as 'one of the economic and political success stories in a continent that is usually excoriated for an unsatisfactory postcolonial democratic record' (Dale, 1999: 128), and claiming that Mauritius has 'proven its ability to sustain a thriving multiparty democracy' (Bowman, 1991: 100). It would also seem that that the democracy-enhancement qualities of small size may be found on the Africa continent. Calculations by the present author suggest that whereas half of the African microstates in 2006 were democracies, the same was true of only one fifth of the larger states.

Finally, all seven microstates in the Middle East and Asia are predominantly non-democratic, and practically all separate classifications of these states are in the nondemocracy category. In all, 14 out of the 16 predominantly oriented microstates in Africa and the Middle East and Asia, and 123 out of 131 separate classifications of these states (= 93\%) are in the non-democracy category. It is obvious, then, that geography makes a difference, and that smallness has been subordinated to regionally defined factors that work against and counterpoise the beneficial impact of small state size on the democratic qualities of political life. In consequence, the relation between small size and democracy, which is visible in other regional contexts, now disappears. All microstates in 2006 in the Middle East and Asia being non-democratic, calculations by the present author show that the same was true of some $80 \%$ of the larger states.

The piling up of democracy cases in the Caribbean and the Pacific when combined with the fact that these regions

Table 3. Impact of Regional Affiliation and Colonial Legacy on the Democratic Status of Microstates. Number of Classifications in Separate Categories

\begin{tabular}{|c|c|c|c|c|}
\hline & \multicolumn{2}{|c|}{ Democracy Classifications Colonial Heritage } & \multicolumn{2}{|c|}{ Non-Democracy Classifications Colonial Heritage } \\
\hline \multicolumn{5}{|l|}{ Region: } \\
\hline Caribbean & 85 & 4 & 14 & 6 \\
\hline Pacific & 44 & 24 & 12 & 18 \\
\hline Europe & 18 & 51 & 6 & 10 \\
\hline Middle East \& Asia & 1 & - & 49 & 12 \\
\hline Totals & 158 & 91 & 102 & 100 \\
\hline
\end{tabular}


are inundated with former British colonies brings up the question of the impact of colonial history on dispositions towards democracy. Conventional wisdom has it that the states which the British left behind them were better equipped for democratic government than the states that had belonged to France or other powers. The reason for this is that more than other metropolitan states Britain applied a reformist strategy, created an administrative and judicial system in the colonies, and familiarized gradually the territories with parliamentary and pluralistic forms of government (e.g. Smith, 1978; Hadenius, 1992: 128-130). Introducing information on the colonial connotations of the democracy classifications, Table 3 addresses this very question, and an inspection of the Table appears to substantiate the conventional wisdom. Whereas a good majority $(=61 \%)$ of the classifications of former British colonies are in the democracy category, the corresponding share of classifications of countries with other colonial histories is $48 \%$ only. Also, out of 20 former British colonies, 13 have performed as predominantly democratic, whereas of 15 former colonies with other than British legacies, only six place themselves in the predominantly democratic camp. The differences in proportions are large enough to suggest that colonial legacy does make a difference, albeit perhaps not a decisive one. The differences also confirm earlier research findings which suggest that former British microstate colonies tend to be more democratic than former non-British microstate colonies (D. Anckar, 2004: 217-219). As evident from the same research (D. Anckar, 2004: 219-220), the smallness-fostersdemocracy thesis also survives in the frame of colonial rule, small former British colonies being predominantly democratic, and larger former British colonies being predominantly non-democratic.

Moreover, the colonial legacy thesis gains in validity if a distinction is introduced between British colonies that were or were not nursed and educated politically by the metropolitan power. Several Arab domiciles are among those territories that did not receive much attention in terms of education from the part of the metropolitan power. The absolute nature of these colonies was in fact never seriously challenged by Britain, who confined herself to being responsible for defense and external affairs, substantial control over internal affairs remaining with the national absolutist regime. A case in point is Kuwait, where in 1899 Sheikh Mubarak negotiated a treaty with Britain that secured Kuwait's independence from the Ottomans in exchange for British control over its foreign relations, this association with Britain continuing until independence in 1961 (Crystal, 1999: 632). The same pattern reappears in Britain's relations with Bahrain, Brunei, Qatar and also with the Maldives. When and if these cases are removed from calculations, the finding is now that $75 \%$ of the classifications of former British colonies are in the democracy category, and that 13 out of 15 British microstate colonies have remained predominantly democratic.

\section{CONCLUSIONS}

The point of departure for this study of microstate democracy was the notion of small state size being particularly conducive to democracy. In itself, the notion has not stand unchallenged, as it has been argued, already in the
Federalist Papers, that small units are particularly vulnerable to the risk of the tyranny of the majority, whereas larger units by generating different coalitions are likely to advance democratic legitimacy (Hamilton, Madison \& Jay, 1961: 82-84; cf Dahl \& Tufte, 1973: 10-11; C. Anckar, 2008). Given, however, the many recent findings that ward off the challenge, the notion of a link between small size and democracy must be regarded well anchored in the present state of research, and this study has for its part contributed to the belief that small states are indeed democratic to a larger extent than larger states.

Still, this study has provided a challenge, albeit one of a different kind. It was the ambition of this study to probe into the robustness in terms of time and space of the belief that size correlates with democracy, and findings are that the robustness is less than convincing in both respects. For one thing, still a couple of decades ago the majority of the microstates of the world were to be classified as nondemocracies. More than larger states, they were advocates and representatives of democratic government, but this pattern was still not prevalent or dominant. Also, while the link between smallness and democracy is now evident in most corners of the world, there are still regions where the link is missing, democracy being a scantiness product and most states, large and small alike, accordingly being nondemocracies.

From these observations, two conclusions emerge:

(1) One good explanation for the democracy conversion of microstates has been hinted at in this study. This explanation focuses on diffusion. Important colonial actors like Britain and USA have in the decolonization processes promoted and encouraged democracy; indeed, it has been said that the prevalence of Westminster-style systems in former British colonies is a product of forced diffusion (Peters, 1998: 42). However, the spreading and prevalence of small state democracy is certainly about more than diffusion alone. Initially socialized by British colonialism, many small states have at later stages of their political life sustained a remarkable fidelity to democratic ideals. Also, as non-democracies have over time developed into democracies, small states have, as demonstrated in this study, internalized an inclination to impel such developments and displayed a capacity to overcome transition difficulties. Today, the vast majority of the microstates of the world are in the nucleus of the democracy universe. There appears indeed to be something to smallness that calls forth and nourishes democratic qualities.

It is not clear at all, however, what constitutes this "something". As stated here earlier, the mechanisms that link small size and democracy remain under-researched, and research in this area also confronts particular difficulties. In their theoretically path-breaking but empirically fairly low-profiled classical study on Size and Democracy Robert Dahl and Edward Tufte list several areas where small size can be expected to influence popular government (Dahl \& Tufte, 1973: 13-17; also C. Anckar, 2008). Among these areas are: citizen participation (more effective participation), security and order (more voluntary compliance, less coercion), unity and diversity (homogeneity), common interest (easier to 
perceive a relation between self-interest and general interest), loyalties (more loyalty to a single integrated community), emotional life (civic relationship invested with high levels of affect, stronger pressures for conformity to collective norms), and rationality (greater speed and accuracy of communication, more opportunities for gaining knowledge, etc). These assertions are not unproblematic, and do not necessarily always hold god. The homogeneity assumption, to take one example, has been proved questionable and in need of qualification (D. Anckar, 1999). In fact, any attempt to test by means of empirical investigations the validity of the Dahl-Tufte battery or any similar listing (e.g. Anckar \& Anckar, 1995: 220-222) should preferably depart from establishing the extent to which the separate factors really link to smallness.

Furthermore, as evident from empirical research (Hadenius, 1992: 125-126; Anckar \& Anckar, 2000: 230233; C. Anckar, 2008), rather extreme threshold-effects are operating in the terrain between size and democracy, and it would appear that for states larger than microstates no tendency of a relation between size and democracy is detectable. This, then, serves to alert researchers in this field to the dangers inherent in the social science preference for conceptions of continuity ahead of conceptions of dichotomy (Sartori, 1970: 1044). Indeed, studies of the impact of size may produce false results when and if all size differences are regarded equal, and researchers are therefore well advised to internalize the thought that some differences are more important than others and to especially acknowledge the importance of threshold effects. Namely, the method of correlating size with other factors implies that small size is one value out of many on a size scale, whereas studies that focus on smallness rather than size perceive smallness as a category per se; in consequence, findings that variations in size are not systematically related to the actual phenomenon under study do therefore not necessarily speak against the observation that small states behave systematically in a different manner than normal-sized and large states. In correlation analyses observations on middle-sized and large units influence the conclusions that may be reached about small units, and if the study of small units reveals a relation that is absent in the other categories, this relation is likely to disappear in exercises that do not keep the categories apart, but rather lump them together and permit that they tinge each other.

(2) Given the regional imbalances in democratic coverage, it would appear that the democracy-promoting qualities of smallness are still not evident or forceful enough to penetrate all barriers. While this is certainly true, it is also true, however, that there are sporadic signs of smallness being able to cultivate, to some extent at least, soils that are commonly regarded as infertile in terms of democracy spreading. It is an apposite observation that of the altogether 11 African democracies in 2006, more than half were countries with populations of less than 2 million (Botswana, Cape Verde, Lesotho, Mauritius, Namibia, Sao Tomé and Príncipe). Concerning the Middle East, in this region, in the language of Freedom House evaluations, 'the roots of democracy and freedom are weakest' (Karatnycky, 1999: 120), and the region has proved 'troublingly resistant to democratization' (Karatnycky, 2003: 101; also Karvonen, 2008: 79). Still, it is worth noting that in this democracy-repelling region the microstate Qatar has engaged, although with caution, in institution-building and political and bureaucratic reform, these efforts including elections since 1998 to municipal councils and a constitution-approving referendum in 2003 (Bahry, 1999; Peterson, 2006: 742743). Also, another microstate in the region, the Kingdom of Bahrain, has in 2002 and again in 2006 held parliamentary and municipal elections, although mired in controversy. Recent findings suggest that there is a fairly broad support for democracy in the Arab world and that Islam does in itself not necessarily foster antidemocratic attitudes; it must remain an open question, though, to what extent popular support for democracy will become transformed into pressure for political reform and democratic openings in the Arab world (Jamal \& Tessler, 2008: 108-109). Likewise, a recent study argues that the failure of the Arab world to undergo a transition to democracy is not because civil-society actors do not support democracy but because of a lack of a consensus that would challenge the post-independence hegemony that underpins authoritarianism (Pratt, 2007). The prospects of the small states in the region eventually making a difference are certainly there, but should perhaps not be overstated. In the same manner as a favorable regional context may ease transitions to democracy, as was the case when Greece, Portugal and Spain benefited from their position close to the heartland of European democracy (Hague \& Harrop, 2004: 47), a non-favorable context is likely to place obstacles in the way of democratization.

\section{REFERENCES}

Alasia, S. (1989). Politics. In H. Laracy (Ed.), Ples Blong Iumi. Solomon Islands, the Past Four Thousand Years (pp. 137-151). Suva: Institute of Pacific Studies, University of the South Pacific.

Alley, R. (2000). The Coup Crisis in Fiji. Australian Journal of Political Science, 35 (3), 515-521.

Anckar, C. (2008). Size, Islandness, and Democracy: A Global Comparison. International Political Science Review, 29 (4), 433-459.

Anckar, D. (1999). Homogeneity and Smallness: Dahl and Tufte Revisited. Scandinavian Political Studies, 22 (1), 29-44.

Anckar, D. (2002). Why are Small Island States Democracies? The Round Table, 365, 375-390.

Anckar, D. (2004). Regime Choices in Microstates: The Cultural Constraint. Journal of Commonwealth \& Comparative Politics, 42 (2), 206223.

Anckar, D. (2007). Archipelagos and Political Engineering: The Impact of Non-Contiguity on Devolution in Small States. Island Studies Journal, 2 (2), 193-208.

Anckar, D., \& Anckar, C. (1995). Size, Insularity and Democracy. Scandinavian Political Studies, 18 (4), 211-229.

Anckar, D., \& Anckar, C. (2000). Democracies without Parties. Comparative Political Studies, 33 (2), 225-247.

Anderson, T. D. (1999). Grenada. In D. A. Kaple (Ed.), World Encyclopedia of Political Systems and Parties (pp. 429-431). Vol. II, Third edition. New York: Facts on File.

Arutangai, S. (1995). Post-Independence Developments and Policies. In H. van Trease (Ed.), Melanesian Politics. Stael Blong Vanuatu (pp. 59-71). Christchurch: Macmillan Brown Centre for Pacific Studies, University of Canterbury.

Bahry, L. (1999). Elections in Qatar: A Window of Democracy Opens in the Gulf. Middle East Policy, 6 (4), 118-127.

Bowman, L. W. (1991). Mauritius. Democracy and Development in the Indian Ocean. Boulder and San Francisco: Westview Press.

Clague, C., Glenson, S., \& Knack, S. (2001). Determinants of Lasting Democracy in Poor Countries: Culture, Development and 
Institutions. Annals of the American Academy of Political and Social Science, 573, 16-41.

Clemente-Kersten, A. C. (1999). Cape Verde. In D. Nohlen, M. Krennerich., \& B. Thibaut (Eds.), Elections in Africa. A Data Handbook (pp. 189-204). Oxford: Oxford University Press.

Crystal, J. (1999). Kuwait. In D. A. Kaple (Ed.), World Encyclopedia of Political Systems and Parties (pp. 632-636). Vol. II, Third edition. New York: Facts on File.

Dahl, R. A., \& Tufte, E. R. (1973). Size and Democracy. Stanford: Stanford University Press.

Dale, R. (1999). Republic of Botswana. In D. A. Kaple (Ed.), World Encyclopedia of Political Systems and Parties (pp. 128-131). Vol. I, Third edition. New York: Facts on File.

Davidson, S. (1987). Grenada. A Study in Politics and the Limits of International Law. Aldershot: Gower Publishing.

Davies, J. E. (2005). Ethnic Competition and the Forging of the NationState of Fiji. The Round Table, 378, 47-76.

Derbyshire, J. D., \& Derbyshire, I. D. (1999). Political Systems of the World, Vols. 1 and 2. Oxford: Helicon Publishing.

Dew, E. (1994). The Trouble in Suriname, 1975-1993. Westport, Conn.: Praeger.

Diamond, L., \& Tsalik, S. (1999). Size and Democracy: The Case for Decentralization. In L. Diamond (Ed.), Developing Democracy: Toward Consolidation (pp. 117-160). Baltimore: John Hopkins University Press.

Duursma, J. (1994). Self-Determination, Statehood and International Relations of Micro-States. Leyden: University of Leyden.

Fleischhacker, H. (1999). Sao Tomé and Príncipe. In D. Nohlen, M. Krennerich, \& B. Thibaut (Eds.), Elections in Africa. A Data Handbook (pp. 739-754). Oxford: Oxford University Press.

Foweraker, J., \& Krznaric, R. (2000). Measuring Liberal Democratic Performance: An Empirical and Conceptual Critique. Political Studies, 48 (4), 759-787.

Griffith, I., \& Sedoc-Dahleberg, B. N. (1997). Introduction: Democracy and Human Rights in the Caribbean. In I. Griffith \& B. N. SedocDahleberg (Eds.), Democracy and Human Rights in the Caribbean (pp. 1-11). Boulder, Colorado: Westview Press.

Hadenius, A. (1992). Democracy and Development. Cambridge: Cambridge University Press.

Hague, R., \& Harrop, M. (2004). Comparative Government and Politics. An Introduction. $6^{\text {th }}$ edition. New York: Palgrave MacMillan.

Hamilton, A., Madison, J., \& Jay, J. (1961). The Federalist Papers. New York: New American Library.

Hassall, G. (2007). Elite Conflict in Vanuatu. In M. A. Brown (Ed.), Security and Development in the Pacific Islands (pp. 225-247). Boulder, Colorado: Lynne Rienner Publishers.

Huntington, S. (1991). The Third Wave: Democratization in the Late Twentieth Century. Norman, Oklahoma: University of Oklahoma Press.

Jamal, A., \& Tessler, M. (2008). Attitudes in the Arab World. Journal of Democracy, 19 (1), 97-110.

Joseph, S. J. (1999). Cyprus. Ethnic Conflict and International Politics, New York: St Martin's Press.

Karatnycky, A. (1999). The 1998 Freedom House Survey. The Decline of Illiberal Democracy. Journal of Democracy, 10 (1), 112-125.

Karatnycky, A. (2003). The $30^{\text {th }}$ Anniversary Freedom House Survey. Liberty's Advances in a Troubled World. Journal of Democracy, 14 (1), 100-113.

Karvonen, L. (2008). Diktatur. Om ofrihetens politiska system. Stockholm: SNS Förlag.

Kay, R. (1993). Fiji. Hawthorn: Lonely Planet Publications.

Lal, B. V. (2007). 'Anxiety, Uncertainty, and Fear in Our Land': Fiji's Road to Military Coup, 2006. The Round Table, 389, 135-153.

Larmour, P. (2005). Foreign Flowers. Institutional Transfer and Good Governance in the Pacific Islands. Honolulu: University of Hawai'i Press.
Lawson, S. (1991). The Failure of Democratic Politics in Fiji. Oxford: Clarendon Press.

Lawson, S. (1996). Tradition versus Democracy in the South Pacific: Fiji, Tonga and Western Samoa. Cambridge: Cambridge University Press.

Lewis, L. (2001). Forbes Burnham (1923-85). Unravelling the Paradox of Postcolonial Charismatic Leadership in Guyana. In A. Allahar (Ed.), Caribbean Charisma. Reflections on Leadership, Legitimacy and Populist Politics (pp. 92-120). Boulder \& London: Lynne Rienner Publishers.

Lijphart, A. (1999). Patterns of Democracy. Government Forms and Performance in Thirty-Six Countries. New Haven: Yale University Press.

Manley, R. H. (1999). Cooperative Republic of Guyana. In D. A. Kaple (Ed.), World Encyclopedia of Political Systems and Parties (pp. 447-450). Vol. II, Third edition. New York: Facts on File.

Moore, C. (2007). External Intervention: The Solomon Islands Beyond RAMSI. In M. A. Brown (Ed.), Security and Development in the Pacific Islands (pp. 169-196). Boulder, Colorado: Lynne Rienner Publishers.

Ott, D. (2000). Small is Democratic: An Examination of State Size and Democratic Development. New York: Garland.

Peters, B. G. (1998). Comparative Politics. Theory and Methods. London: Macmillan Press.

Peterson, J. E. (2006). Qatar and the World: Branding for a Micro-State. Middle East Journal, 60 (4), 732-748.

Pratt, N. (2007). Democracy \& Authoritarianism in the Arab World. Boulder, Colorado: Lynne Rienner Publishers.

Puddington, A., \& Piano, A. (2005). The 2004 Freedom House Survey. Worrisome Signs, Modest Shifts. Journal of Democracy, 16 (1), 103-108.

Royle, S. A. (2001). A Geography of Islands. Small Island Insularity. London and New York: Routledge.

Sartori, G. (1970). Concept Misformation in Comparative Politics. The American Political Science Review, 64 (4), 1033-1053.

Senituli, L. (2007). Unfinished Business: Democratic Transition in Tonga. In M. A. Brown (Ed.), Security and Development in the Pacific Islands (pp. 265-286). Boulder, Colorado: Lynne Rienner Publishers.

Smith, A. (1978). A Comparative Study of French and British Decolonization. Comparative Studies in Society and History, 20 (2), 70-102.

Soudriette, R. W., \& Ellis, A. (2006). Electoral Systems Today. A Global Snapshot. Journal of Democracy, 17 (2), 78-88.

Srebrnik, H. (2004). Small Island Nations and Democratic Values. World Development, 32 (2), 329-341.

Stepan, A., \& Skach, C. (1994). Presidentialism and Parliamentarism in Comparative Perspective. In J. J. Linz, \& A. Valenzuela (Eds.), The Failure of Presidential Democracy (pp. 119-136). Baltimore and London: The Johns Hopkins University Press.

Thorndike, T. (1990). Suriname. In World Economic and Business Review 1990 (pp. 616-619). Oxford: Blackwell Reference, Basil Blackwell.

van Trease, H. (1995 a). Colonial Origin of Vanuatu Politics. In H. Van Trease (Ed.), Melanesian Politics. Stael Blong Vanuatu (pp. 3-58). Christchurch: Macmillan Brown Centre for Pacific Studies, University of Canterbury.

van Trease, H. (1995 b). Years of Turmoil: 1987-91. In H. van Trease (Ed.), Melanesian Politics. Stael Blong Vanuatu (pp. 73-118). Christchurch: Macmillan Brown Centre for Pacific Studies, University of Canterbury.

Vanhanen, T. (1990). The Process of Democratization. A Comparative Study of 147 States, 1980-88. New York: Taylor \& Francis.

http://www.freedomhouse.org/template.cfm?page $=15$ (accessed January 79, 2008).

http://www.populstat.info/ (accessed January 7-9, 2008).

World Economic and Business Review 1990 (1990). Oxford: Blackwell Reference, Basil Blackwell.

Received: July 25, 2008

Revised: September 26, 2008

Accepted: September 26, 2008

(C) Dag Anckar; Licensee Bentham Open.

This is an open access article licensed under the terms of the Creative Commons Attribution Non-Commercial License (http://creativecommons.org/licenses/by-nc/3.0/) which permits unrestricted, non-commercial use, distribution and reproduction in any medium, provided the work is properly cited. 